\title{
Factor Analytic Study of Lecturer's Teaching Assessment Scale in Obafemi Awolowo University, Nigeria
}

\author{
Olu Philip Jegede ${ }^{1}$, Bamidele Abiodun Faleye ${ }^{2, *} \&$ Emily Oluseyi Adeyemo ${ }^{2}$ \\ ${ }^{1}$ Institute of Education, Faculty of Education, Obafemi Awolowo University, Ile-Ife, Nigeria \\ ${ }^{2}$ Department of Educational Foundations and Counselling, Faculty of Education, Obafemi Awolowo University, \\ Ile-Ife, Nigeria \\ *Correspondence: Department of Educational Foundations and Counselling, Faculty of Education, Obafemi \\ Awolowo University, Ile-Ife 220005, Nigeria. Tel: 234-803-507-1524 E-mail: bafaleye@oauife.edu.ng \\ Received: February 2, $2015 \quad$ Accepted: June 1, $2015 \quad$ Online Published: June 14, 2015 \\ doi:10.5430/wje.v5n3p121 \\ URL: http://dx.doi.org/10.5430/wje.v5n3p121
}

\begin{abstract}
This study presents a validation report of the Lecturer's Teaching Assessment Scale (LTAS) developed for the assessment of lecturer's teaching effectiveness in Obafemi Awolowo University, Ile-Ife, Nigeria. It also examined the factor structure of the LTAS, its construct validity, and internal consistency reliability coefficients. The study adopted the survey research design. A total of 13,000 students that completed the LTAS online constituted the sample for the study. The 34-item LTAS was used to collect data for the study. Collected data were subjected to reliability and factor analyses. Results showed that the LTAS has two subscales - Attitude to Teaching and Lecture Presentation and Organisation. The LTAS was adjudged to possess construct validity, and it was established through experts' judgement. The results also revealed that the LTAS was reliable (Cronbach Alpha reliability coefficient of 0.985, Spearman Brown's Split-half reliability coefficient of 0.998 and Gutman's Split-half coefficient of 0.997). Thus, the LTAS possessed adequate psychometric qualities that make it suitable for use among Nigerian undergraduate students.
\end{abstract}

Keywords: scaling; teaching assessment; validation; reliability analysis; lecturer's assessment

\section{Introduction}

Over the years, the assessment of academic members of staff during annual review of lecturers in Obafemi Awolowo University, Ile-Ife, Nigeria has been largely subjective as there was no formal, reliable and valid evidence to substantiate the rating of the quality of teaching of academic staff by their respective Heads of Department. The university recently became determined to ensure that lecturers are more committed to working hard than it was in the past, sustain its good rating via webometric ranking among its pairs in Nigeria and on the continent of Africa (Webometric ranking is a site that provides ranking of universities across the world. The site started publishing the ranking of universities in 2004 and the criteria for making the ranking are available on the website at http://www.webometrics.info/) and ensure excellence in learning and culture by trying to put into use an evidence-based approach for the assessment of every lecturer at the end of every semester, with a view to ensuring that lecturers strive to deliver their instructions with all the seriousness and innovations capable of enhancing learning positively.

It was in the light of the foregoing that the Lecturers Teaching Assessment Scale (LTAS) was introduced to students for the assessment of the quality of teaching of academic members of staff in Obafemi Awolowo University, Ile-Ife, Nigeria. The LTAS is due for completion online (via the university's electronic portal) at the end of lecture periods of every semester by students who might have finished at least the first semester of 200 level (i.e. first semester of Part Two). This decision was exemplified by the fact that Lecturers themselves (having the premonition that their activities will be subjected to this type of assessment at the end of the semester) will be motivated to do better in the discharge of their teaching duties, and this will impact positively on students' learning because research findings have demonstrated that effective teaching leads to good academic performance in courses (Abdulkadir, 2006).

The need for this type of assessment may be rooted in McGregor's theory X and theory $\mathrm{Y}$ as well as Herzberg's Hygiene and Motivational Factors Theory (Vroom and Deci, 1970 cited from Opu, 2008). McGregor's theory 
explains people's perceptions of employee work behaviour. Theory X views an average worker as indolent, someone who would always want to seize the opportunity to derelict whenever there is the chance. Thus, they should be forced to work. Theory $\mathrm{Y}$ however views an average employee as being rational, someone that does not need to be coerced before doing his/her job. The belief of those that embrace theory X could have influenced the university management to adopt the LTAS. May be, at one point or the other, it was noticed that some members are not performing their teaching duties as expected.

Herzberg's hygiene and motivational theory on the other hand divides the employees job environment into two, namely the dissatisfiers and the motivators. Dissatisfiers include working conditions, company policies and administrative practices, salary and benefits, supervision, status, job security co-workers and personal life while the motivators include factors such as recognition, achievement, advancement, growth, responsibility and job challenge. One set of needs is associated with what a person does while the other is concerned with the situation in which it is done. The motivators are the factors that spur an employee to work effectively, bearing in mind that there is a link between the work done and the rewards that will accrue through the dissatisfiers.

The two theories (i.e. McGregor's theory X and theory Y as well as Herzberg's hygiene and motivational theory) become relevant to the situation in Obafemi Awolowo University because in every workplace, two shades of workers are most likely to be hired - the very committed and hardworking members of staff as well as the indolent and lazy type. Although, authors have no statistic of who has been committed and who has not been, but the believe is that a number of hired staff in the university have not been committed enough. This, coupled with the need for defensible proof in the assessment of lecturers' teaching assessment prompted the university to commence the online assessment of lecturers teaching effectiveness.

A key problem is that current measures for assessing academics for promotion in most Nigerian Universities are not often linked to their capacity to teach effectively. Existing Federal University policies for measuring teacher effectiveness either rely almost exclusively on perception by heads of departments, or focus on teachers' course-taking records and on paper-and-pencil tests of basic academic skills and subject matter knowledge. Also, criteria for assessing academics for promotion in most Nigerian universities include qualifications, publications and community service at the local, national or international levels, all these, research as exemplified by research, are poor predictors of teaching effectiveness (Adomi and Mordi, 2003; Faleye and Awopeju, 2012).

The LTAS is a 34-item scale containing five sub-scales. These are Lecturer's Attitude to Teaching, Organisation and Presentation, Verbal and Non-Verbal Communication, Teacher-Student Relationship and Feedback. The LTAS has not been previously validated. It is however important that any measurement instrument undergoes normal psychometric scrutiny before subjecting it to public use (DeVellis, 2012). The same justification was advanced by Faleye and Awopeju (2012) concerning the Students' Evaluations of Teaching Effectiveness Rating Scale (SETERS), which was said to be useful in assessing teaching effectiveness in Western Countries. However, its suitability for use in Nigeria has not been established. Even though, there is still a dearth of comparable validated instruments for assessing the effectiveness of lecturers' teaching (such as the LTAS) using Nigerian samples, research and theory have shown that teaching assessment, as measured by students' rating of teaching, is multidimensional in nature. Hence, the conflicting factor structure of student evaluation of teaching as experienced in the validation of SETERS (Faleye and Awopeju, 2012), where different psychometric characteristics were obtained between the original version published by Tonad, and DeAyala (2005) and that by Faleye and Awopeju (2012) as well as the call for further validation efforts geared towards the improvement of the quality of SETERS also explain the need for this study.

Finally, the LTAS has not been previously validated. The university only relied on expert's judgement of the appropriateness of the instrument, the relevance of individual items on the LTAS as well as its ease of use by the students. There is therefore the need for a scientific investigation of the psychometric qualities of the instrument, hence this study.

The LTAS took its root from SETERS (Faleye and Awopeju, 2012) which had many of its items adopted from SETERS developed in the United State of America (Tonad, and DeAyala, 2005), a culture and environment different from Nigeria's; there is therefore the need for cross-cultural validation of SETERS. As recommended by many authors that scales be cross-validated before use once such scales are to be used in different cultures and national boundaries (Tschannen-Moran, Woolfolk-Hoy \& Hoy, 1998; Brouwers, 2003 and DeVellis, 2012). Moreover, previous researchers, Toland and De Ayala (2005) saw a need for additional empirical research on the SETERS before widespread use, ditto for the LTAS.

In validating instruments, emphasis is placed on the degree to which the instrument is adjudged to be valid, reliable 
and usable with minimal fear of committing generalization error Devellis (2012). The normal thing to do is to construct more items than the actual number needed for the actual measurement of the variable of interest. This is to ensure that there will be enough left for respondents to attempt, which will adequate elicit sufficient information required to properly (or reliably/validly) understand the variable of investigation (Nunally and Bernstein, 1994).

Arising from the foregoing, one may wish to ask some pertinent questions such as

i. how reliable is LTAS?

ii. are the items of LTAS significant in measuring teaching effectiveness?

iii. Could the LTAS assess lecturers effectively?

The specific objectives of this study were to

i. examine the factor structure of LTAS;

ii. investigate the construct validity of LTAS;

iii. determine the internal consistency reliability coefficients of LTAS;

In order to be able to carry out this study effectively, the following research questions were raised:

i. What is the factor structure of LTAS?

ii. Does the LTAS possess construct validity?

iii. What is the coefficient of LTAS' internal consistency reliability?

\section{Methods}

This study adopted the survey design. The population of this study comprised all undergraduate students of Obafemi Awolowo University, Ile-Ife, Nigeria. The university has a total of 13 faculties with a population of about 26,000 students. A sample of 13,000 was drawn purposively comprising 1000 students from each of the 13 faculties. The selected sample was made of 5,904 males and 7,096 female students with an average age of 19.6 years. The 13,000 selected were those that responded to all the 34 items on the LTAS. The LTAS is to be completed (by every student) for each lecturer that participated in the teaching of each of their courses of study. This means that each student may have to complete the form many times depending on the number of courses taken by each student as well as the number of lecturers that taught each of such courses. Thus, for the purpose of validation, only 1000 of responses to the LTAS from each of the 13 faculties were included in this study. The students were undergraduate students of the university and the sample is inclusive of a mix of students across the 82 departments in the university. The students are those in second to the fifth year of their programme, depending on duration of programme. The items on LTAS are positively stated and there is no need for reversal of scores for any item. The response format for the LTAS is the Likert type comprising of Always, Sometimes, Rarely and Never; and the scoring relating to each of the four response options are 4, 3, 2 and 1 respectively. Data collected were analysed using factor and reliability analyses.

\section{Results}

The results of the student's responses to the items of LTAS were subjected to factor and reliability analyses. The collected data were subjected to Principal Component Analysis (initial rotation). Furthrmore, the construct validity of the LTAS was determined by three other experts in the of Tests and Measurement for appropriateness of items in terms of wordings, lentgh and relevants of the items contained in the LTAS. Furtherstill, the data was also subjected to reliability analysis; specifically the internal consistency reliabilities of Cronbach's Alpha and Split-half types were investigated.

\subsection{Research Question 1: What Is the Factor Structure of LTAS?}

The data obtained from students'response to the LTAS were subjected to factor analysis. The maximum likehood estimate with varimax rotation was employed to understand the factor structure of the LTAS. However, the KMO and Batlet's test of sampling adequacy and sphericity of data produced the results in Table 1 
Table 1. KMO and Bartlett's Test Results for Suitability of LTAS Data for factor Analysis

\begin{tabular}{lrr}
\hline - Kaiser Meyer-Olkin Measure of Sampling Adequacy. & 0.931 \\
Bartlett's Test of Sphericity & Approx. Chi-Square & $2.338 \mathrm{E} 4$ \\
& Df & 561 \\
& Sig. & .000 \\
\hline
\end{tabular}

The results in Table 1 showed that the LTAS elicited a set of data that produced a very high KMO value of 0.93 as well as a Chi-square value of 2.34 , which was significant at 0.05 level. Thus, from these values, the data elicited by the LTAS were suitable for factor analysis.

The underlisted item means and standard deviations were obtained from the administration of the LTAS on the undergraduate stuents of OAU and are as presented in Table 2.

Table 2. Item Means and Standard Deviation of Students'Responses to LTAS(to be continued)

\begin{tabular}{|c|c|c|c|}
\hline Item No. & Item & Mean & Std. Deviation \\
\hline Item1 & $\begin{array}{l}\text { The lecturer teaches for the number of hours required for teaching the course } \\
\text { per week e.g. } 3 \text { hours for a } 3 \text {-unit course; } 2 \text { hours for a } 2 \text {-unit course }\end{array}$ & 3.7094 & .73502 \\
\hline Item2 & $\mathrm{He} /$ She comes for lectures punctually & 3.7434 & .69781 \\
\hline Item3 & $\mathrm{He} /$ She teaches for the whole length of the period & 3.7396 & .68820 \\
\hline Item4 & $\begin{array}{l}\text { He/She shows evidence of adequate preparation by logically presenting } \\
\text { subject matter }\end{array}$ & 3.6679 & .70919 \\
\hline Item5 & $\begin{array}{l}\mathrm{He} / \text { She provides lecture notes and/or refers students to available texts and } \\
\text { other sources of information }\end{array}$ & 3.6566 & .76809 \\
\hline Item6 & $\mathrm{He} /$ She introduces the lecture in an interesting way & 3.7019 & .74734 \\
\hline Item7 & $\begin{array}{l}\text { He/She provides useful presentation indicators e. g. gives outlines, states } \\
\text { objectives, reviews main points }\end{array}$ & 3.6906 & .78002 \\
\hline Item8 & $\begin{array}{l}\mathrm{He} / \text { She uses relevant and practical exercises to clarify ideas and make the } \\
\text { lesson interesting }\end{array}$ & 3.6415 & .87677 \\
\hline Item9 & $\begin{array}{l}\mathrm{He} / \text { She presents challenging and thought-provoking ideas to stimulate } \\
\text { reflective and critical thinking }\end{array}$ & 3.6528 & .90466 \\
\hline Item 10 & $\mathrm{He} / \mathrm{She}$ relates subject matter to current events and students' interests & 3.6264 & .98091 \\
\hline Item 11 & $\begin{array}{l}\text { He/She welcomes and encourages ideas, comments, questions and students' } \\
\text { active participation }\end{array}$ & 3.7019 & 96029 \\
\hline Item 12 & $\begin{array}{l}\mathrm{He} / \text { She uses a variety of activities, methods, techniques, media and teaching } \\
\text { aids to complement teaching }\end{array}$ & 3.6189 & 1.06690 \\
\hline Item 13 & $\begin{array}{l}\mathrm{He} / \text { She encourages and supervises interactive activities such as small group } \\
\text { discussions, student presentations and solving problems in groups }\end{array}$ & 3.5585 & 1.16668 \\
\hline Item14 & $\begin{array}{l}\text { He/She encourages students to answer questions e. g. waits for answer, } \\
\text { rephrases questions }\end{array}$ & 3.6453 & 1.19762 \\
\hline Item 15 & $\begin{array}{l}\text { He/She uses illustrations, graphs, diagrams and other relevant instructional } \\
\text { resources such as films, tapes, maps, slides to complement teaching }\end{array}$ & 3.3623 & 1.50406 \\
\hline Item16 & $\begin{array}{l}\text { He/She presents technical and difficult concepts slowly, in simple everyday } \\
\text { English }\end{array}$ & 3.6038 & 1.38087 \\
\hline Item 17 & $\mathrm{He} / \mathrm{She}$ writes key terms on the board or uses multimedia projector & 3.5547 & 1.51189 \\
\hline Item18 & $\mathrm{He} /$ She ensures understanding of a concept before proceeding to another & 3.6226 & 1.51541 \\
\hline Item19 & $\mathrm{He} /$ She delivers the lecture without excessive reliance on reading lecture notes & 3.6491 & 1.58157 \\
\hline Item20 & $\mathrm{He} /$ She answers questions asked by students satisfactorily & 3.6981 & 1.63514 \\
\hline Item 21 & $\mathrm{He} / \mathrm{She}$ is mindful of his/her speed when delivering the lecture & 3.6981 & 1.70544 \\
\hline
\end{tabular}


Table 2. (Continued)

\begin{tabular}{|c|c|c|c|}
\hline Item No. & Item & Mean & Std. Deviation \\
\hline Item22 & $\mathrm{He} /$ She speaks loudly and clearly & 3.7057 & 1.79334 \\
\hline Item 23 & $\begin{array}{l}\text { He/She speaks fluently without distracting verbal and/or non-verbal } \\
\text { mannerisms }\end{array}$ & 3.8000 & 1.83237 \\
\hline Item 24 & $\begin{array}{l}\text { He/She focuses on the students and maintains eye contact with them during the } \\
\text { lecture }\end{array}$ & 3.8377 & 1.90098 \\
\hline Item 25 & $\mathrm{He} / \mathrm{She}$ commands respect and treats students with respect & 3.8226 & 1.99304 \\
\hline Item 26 & $\begin{array}{l}\text { He/She is ready to help students when faced with learning difficulties in and } \\
\text { out of the lecture room }\end{array}$ & 3.7887 & 2.08727 \\
\hline Item 27 & $\mathrm{He} / \mathrm{She}$ is approachable and shows interest in his/her students' progress & 3.7925 & 2.16514 \\
\hline Item 28 & $\mathrm{He} /$ She maintains discipline in and out of the lecture room & 3.8075 & 2.25394 \\
\hline Item 29 & $\begin{array}{l}\mathrm{He} / \text { She ensures that students attend lectures regularly by taking weighted } \\
\text { attendance }\end{array}$ & 3.7698 & 2.37487 \\
\hline Item30 & $\mathrm{He} / \mathrm{She}$ conducts and/or gives assignments & 3.7208 & 2.47513 \\
\hline Item31 & $\mathrm{He} / \mathrm{She}$ asks questions in line with course objectives & 3.8566 & 2.48522 \\
\hline Item32 & $\begin{array}{l}\text { He/She evaluates students fairly e. g. assigns appropriate percentages for } \\
\text { continuous assessment and examination }\end{array}$ & 3.7547 & 2.60176 \\
\hline Item33 & $\mathrm{He} / \mathrm{She}$ grades and returns tests and assignments in time & 3.6264 & 2.74139 \\
\hline Item34 & $\mathrm{He} /$ She encourages students to give feedback in the course of the lecture & 3.8302 & 2.74508 \\
\hline
\end{tabular}

A look at the menan values of the 34-item LTAS showed a consistently high mean item value for each of the 34 items. Bearing in mind that the range of value of the response options on LTAS is between four (i.e. highest) and one (lowest). The pattern of students'responses appers to be tilted towards the affirmative of the positive statements contained in the LTAS. The highest item mean is 3.86 while the lowest is 3.36 and the values of standard deviation for every response to the items on the scale ranges between 0.74 and 2.75 . The distribution of students'responses to the LTAS reflects a generally high rating of most lecturers by students. Again, from the raw data, students appeared not different in their rating of their Lecturers on the various dimensions of the scale.

The data from the LTAS was subjected to principal component analysis and the result is a two-factor model as presented in Table 3.

Table 3. Factor Structure of the LTAS(to be continued)

\begin{tabular}{lrrrrrr}
\hline Component & \multicolumn{5}{c}{ Initial Eigenvalues } & \multicolumn{3}{c}{ Extraction Sums of Squared Loadings } \\
\cline { 2 - 6 } & \multicolumn{1}{c}{ Total } & \% of Variance & Cumulative \% & \multicolumn{1}{c}{ Total } & $\begin{array}{c}\text { \% of } \\
\text { Variance }\end{array}$ & $\begin{array}{c}\text { Cumulative } \\
\%\end{array}$ \\
\hline 1 & 25.033 & 73.626 & 73.626 & 25.033 & 73.626 & 73.626 \\
2 & 5.445 & 16.014 & 89.640 & 5.445 & 16.014 & 89.640 \\
3 & .641 & 1.885 & 91.525 & & & \\
4 & .454 & 1.335 & 92.860 & & & \\
5 & .335 & .986 & 93.847 & & \\
6 & .264 & .776 & 94.622 & & \\
7 & .216 & .637 & 95.259 & & & \\
8 & .205 & .604 & 95.863 & & & \\
9 & .174 & .511 & 96.374 & & & \\
10 & .162 & .477 & 96.850 & & & \\
11 & .135 & .398 & 97.248 & & & \\
12 & .131 & .384 & 97.632 & & & \\
\hline
\end{tabular}


Table 3. (Continued)

\begin{tabular}{llll}
\hline 13 & .119 & .350 & 97.982 \\
14 & .096 & .283 & 98.265 \\
15 & .082 & .241 & 98.506 \\
16 & .074 & .218 & 98.724 \\
17 & .066 & .193 & 98.917 \\
18 & .062 & .181 & 99.098 \\
19 & .048 & .140 & 99.239 \\
20 & .041 & .122 & 99.360 \\
21 & .035 & .104 & 99.464 \\
22 & .031 & .091 & 99.555 \\
23 & .026 & .078 & 99.633 \\
24 & .024 & .069 & 99.702 \\
26 & .019 & .055 & 99.816 \\
27 & .013 & .038 & 99.855 \\
28 & .012 & .036 & 99.890 \\
29 & .010 & .028 & 99.919 \\
30 & .009 & .025 & 99.944 \\
31 & .007 & .021 & 99.965 \\
32 & .006 & .016 & 99.982 \\
33 & .004 & .013 & 99.994 \\
34 & .002 & .006 & 100.000 \\
\hline Extration & Method & Principal Component Anars & \\
\hline
\end{tabular}

Extraction Method: Principal Component Analysis.

The suggested number of factors on the LTAS is two. These two factors (with eigenvalues greater than one) account for 89.64 of the total scale variance. This two-factor model is further is further supported by a chi-square value of 4751.84 ( $\mathrm{df}=494, \mathrm{p}<0.05$ ), indicating that the two-factor model is fit for the actual assessment of lecturers. The resulting scree plot also exemplified the two-factor model produced by the principal component analysis. This is as presented in Figure 1.

Scree Plot

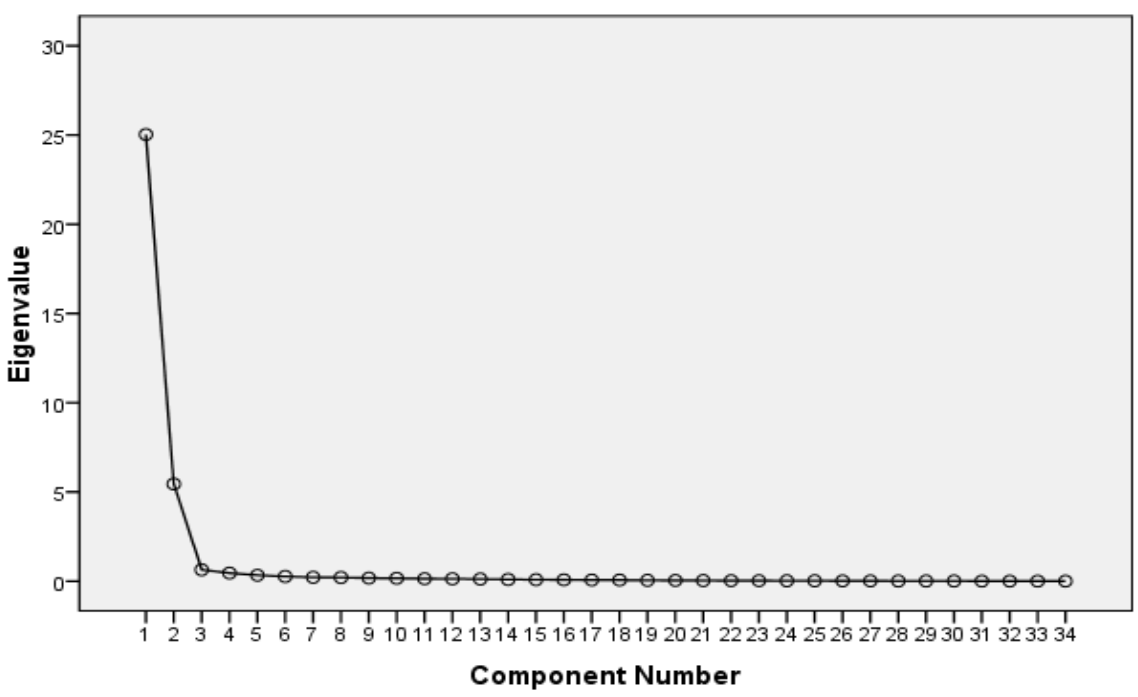

Figure 1. Scree Plot Showing the Number of Factors on the LTAS

The axis of the component path in Figure 1 shows that there are two factors located before the elbow of the axis. This means there are two factors on the scale. However, the initial classification of the dimensions of the LTAS, which was five will now give way for only two factors, they are (i) Attitude to Teaching and (ii) Lecture Presentation and Organisation. The factor loadings for each item is as presented in Table 4. 
Table 4. Item Loadings on the Two Factors

\begin{tabular}{|c|c|c|}
\hline & \multicolumn{2}{|c|}{ Component } \\
\hline & 1 & 2 \\
\hline Item 1 & & .916 \\
\hline Item2 & & .897 \\
\hline Item3 & & .829 \\
\hline Item4 & . & .771 \\
\hline Item5 & & .672 \\
\hline Item6 & .684 & \\
\hline Item7 & .753 & \\
\hline Item8 & .786 & \\
\hline Item9 & .844 & \\
\hline Item 10 & .848 & \\
\hline Item 11 & .917 & \\
\hline Item 12 & .922 & \\
\hline Item 13 & .927 & \\
\hline Item 14 & .949 & \\
\hline Item 15 & .860 & \\
\hline Item 16 & .945 & \\
\hline Item 17 & .931 & \\
\hline Item 18 & .963 & \\
\hline Item 19 & .950 & \\
\hline Item 20 & .963 & \\
\hline Item 21 & .969 & \\
\hline Item 22 & .956 & \\
\hline Item 23 & .956 & \\
\hline Item 24 & .949 & \\
\hline Item 25 & .946 & \\
\hline Item 26 & .949 & \\
\hline Item 27 & .952 & \\
\hline Item 28 & .942 & \\
\hline Item 29 & .931 & \\
\hline Item 30 & .918 & \\
\hline Item31 & .936 & \\
\hline Item 32 & .932 & \\
\hline Item33 & .924 & \\
\hline Item34 & .929 & \\
\hline
\end{tabular}

The loadings of the items showed that only the first five items loaded on Factor 2, which is Attitude to Teaching; while the remaining 29 items loaded on Lecture Presentation and Organisation.

Table 5 presents the values of communalities for each of the items on the LTAS. The results is presented below. 
Table 5. Communality Values of Items on the LTAS

\begin{tabular}{lll}
\hline & Initial & Extraction \\
\hline Item1 & 1.000 & .864 \\
Item2 & 1.000 & .875 \\
Item3 & 1.000 & .828 \\
Item4 & 1.000 & .852 \\
Item5 & 1.000 & .768 \\
Item6 & 1.000 & .852 \\
Item7 & 1.000 & .816 \\
Item8 & 1.000 & .788 \\
Item9 & 1.000 & .836 \\
Item10 & 1.000 & .800 \\
Item11 & 1.000 & .884 \\
Item12 & 1.000 & .870 \\
Item13 & 1.000 & .874 \\
Item14 & 1.000 & .903 \\
Item15 & 1.000 & .743 \\
Item16 & 1.000 & .894 \\
Item17 & 1.000 & .867 \\
Item18 & 1.000 & .931 \\
Item19 & 1.000 & .914 \\
Item20 & 1.000 & .942 \\
Item21 & 1.000 \\
Item22 & 1.000 & .958 \\
Item23 & 1.000 & .939 \\
Item24 & 1.000 & .955 \\
Item25 & 1.000 & .955 \\
Item26 & 1.000 & .956 \\
Item27 & 1.000 & .959 \\
Item28 & 1.000 & .970 \\
Item29 & 1.000 & .961 \\
Item30 & 1.000 & .946 \\
Item31 & .931 \\
Item32 & .960 \\
Item33 & .966 \\
Item34 & & .966 \\
\hline
\end{tabular}

The process of item reduction is done using the values of communality of each of the item. This item retention rule is usually hinged on the elimination of items with communality values of less than 0.5 from scales since the researcher's interest is to obtain values that will be close to one. Looking at Table 5, majority of the communality values are close to one, meaning that they adequately account for the variation that exist in the two-factor model that resulted from the factor analysis of the LTAS. Thus, in its present state, no item appeared inadequate for retention on the scale.

\subsection{Research Question 2: Does the LTAS Possess Construct Validity?}

Construct validity of instruments could be estimated using either of or all of correlation with another instrument measuring a similar variable (Westen and Rosenthal, 2003) relate with an expert to help in judging the extent to which the items on the instrument possesses construct validity. This statement is further supported by the submission of Brown (2000) as quoted below:

"To demonstrate content validity, testers investigate the degree to which a test is a representative sample of the content of whatever objectives or specifications the test was originally designed to measure. To investigate the degree of match, test developers often enlist well-trained colleagues to make judgments about the degree to which the test items matched the test objectives or specifications (p.8).

Thus, the LTAS was reviewed by three other experts in the field of Tests and Measurement. The three hold doctoral 
degree in the field. They were given the first draft of the instrument containing 40 items. The 40 item version was then examined for content relevance, appropriateness of wordings, freedom from ambiguity and multiple interpretations, item length e.t.c. Their examination led to the removal of six items from the 40 items contained in the LTAS, leaving the instrument with 34 items that were adjudged relevant and suitable for the assessment of lecturers.

\subsection{Research Question 3: What Is the Coefficient of LTAS' Internal Consistency Reliability?}

The LTAS was also subjected to internal consistency reliability analysis. Specifically, the Cronbach's alpha coefficient reliability as well as the split-half reliability analyses were investigated. Results showed that the LTAS had a Cronbach Alpha reliability coefficient of 0.985, Spearman Brown's Split-half reliability coefficient of 0.998 and Gutman's Split-half coefficient of 0.997. All these coefficients are very high and are pointers to the fact that the LTAS is a reliable instrument.

When the item-total Statistics of the LTAS was considered using the (SPSS), it was found that all the items on the LTAS are reliable enough and none deserved to be eliminated. The results is as presented in Table 8.

Table 8. Item-Total Statistics of the LTAS

\begin{tabular}{lccccc}
\hline & $\begin{array}{c}\text { Scale Mean if } \\
\text { Item Deleted }\end{array}$ & $\begin{array}{c}\text { Scale Variance } \\
\text { if Item Deleted }\end{array}$ & $\begin{array}{c}\text { Corrected } \\
\text { Item-Total } \\
\text { Correlation }\end{array}$ & $\begin{array}{c}\text { Squared } \\
\text { Multiple } \\
\text { Correlation }\end{array}$ & $\begin{array}{c}\text { Cronbach's } \\
\text { Alpha if Item } \\
\text { Deleted }\end{array}$ \\
\hline Item1 & 121.9472 & 2183.618 & .088 &. & .986 \\
Item2 & 121.9132 & 2177.019 & .195 &. & .986 \\
Item3 & 121.9170 & 2170.001 & .307 &. & .986 \\
Item4 & 121.9887 & 2160.526 & .442 &. & .986 \\
Item5 & 122.0000 & 2153.523 & .506 &. & .986 \\
Item6 & 121.9547 & 2146.240 & .627 &. & .985 \\
Item7 & 121.9660 & 2139.048 & .700 &. & .985 \\
Item8 & 122.0151 & 2129.674 & .738 &. & .985 \\
Item9 & 122.0038 & 2122.473 & .803 &. & .985 \\
Item10 & 122.0302 & 2116.128 & .810 &. & .985 \\
Item11 & 121.9547 & 2110.680 & .891 &. & .985 \\
Item12 & 122.0377 & 2101.097 & .899 &. & .985 \\
Item13 & 122.0981 & 2091.869 & .909 &. & .985 \\
Item14 & 122.0113 & 2086.496 & .935 &. & .984 \\
Item15 & 122.2943 & 2072.655 & .842 &. & .985 \\
Item16 & 122.0528 & 2070.437 & .938 &. & .984 \\
Item17 & 122.1019 & 2060.918 & .925 &. & .984 \\
Item18 & 122.0340 & 2056.041 & .959 &. & .984 \\
Item19 & 122.0075 & 2051.288 & .952 &. & .984 \\
Item20 & 121.9585 & 2044.373 & .968 &. & .984 \\
Item21 & 121.9585 & 2037.366 & .974 &. & .984 \\
Item22 & 121.9509 & 2031.304 & .963 &. & .984 \\
Item23 & 121.8566 & 2027.214 & .967 &. & .984 \\
Item24 & 121.8189 & 2021.982 & .963 &. & .984 \\
Item25 & 121.8340 & 2014.533 & .960 &. & .984 \\
Item26 & 121.8679 & 2005.835 & .963 &. & .984 \\
Item27 & 121.8642 & 1998.391 & .967 &. & .984 \\
Item28 & 121.8491 & 1992.583 & .957 &. & .985 \\
Item29 & 121.8868 & 1984.010 & .948 &. & .985 \\
Item30 & 121.9358 & 1978.598 & .933 &. &. \\
Item31 & 121.8000 & 1973.661 & .953 &. &. \\
Item32 & 121.9019 & 1964.362 & .950 &. & .984 \\
Item33 & 122.0302 & 1954.840 & .940 &. &. \\
Item34 & 121.8264 & 1953.296 & .945 &. &. \\
\hline & & & &. &. \\
& &. &. & \\
& &. &. \\
\end{tabular}

The value of the scale's 'Cronbach's Alpha If Item Deleted' falls between 0.984 and 0.986 for all the items on the 
LTAS. This means that no major increase in Cronbach's alpha reliability coefficient will be achieved for the scale upon the removal of the items on the instrument.

\section{Discussion}

The results obtained showed that most lecturers enjoyed positive (and high) rating by students. This could be as a result of the awareness of academic members of staff across all the teaching units in the university that their teaching duty will be assessed by the students at the end of the semester. Not only this, the results of students' assessment of every lecturer will also be incorporated into the process of review for promotion of the lecturer(s) concerned. These are enough factors to spur lecturers to teaching well. The finding is in line with the submission of Wood (2000), that when employees are motivated to achieve a target, the reward that follows such an achievement motivates the employee to work hard. This is also in line with McGregor's theory X, as well as Herberg's hygiene and motivation theory. It is a matter of common knowledge that commitment to duty has greatly improved since the introduction of the LTAS. The outcome of this study is also in line with the conclusion of Faleye and Awopeju (2012), when they investigated the psychometric characteristics of SETERS, and they concluded that the instrument possessed appropriate psychometric characteristics that made its use appropriate on Nigerian sample.

\section{Conclusion}

The 34-item LTAS in its current format has acceptable psychometric features and thus, it could adequately measure the quality of lecturer's teaching.

\section{References}

Abdulkadir, HS. (2006). Strategies for improving the efficiency of teachers in Jigawa State [dissertation]. [Nsukka]: University of Nigeria, Nsukka.

Adomi, EE., \& Mordi, C. (2003). Publication in foreign journals and promotion of academics in Nigeria. Learned Publishing, 16(4), 259-63. http://dx.doi.org/10.1087/095315103322421991

Brouwers, A. (2013). A test of the factorial validity of the teacher efficacy scale Research. Research in Education; 2003. Retrieved $12^{\text {th }} \quad$ February, 2007 from http://www.findarticles.com/particles/mi+qa3765/is_200305/ai_n919453/print

Brown, JD. (2014). What is Construct Validity? Shiken: JALT Testing \& Evaluation SIGNewsletter, 4(2), 8-12.

DeVelllis, R. (2015). Scale Development: Theory and Applications. Newbury Park (CA): Sage.

Faleye, BA., \& Awopeju, OA. (2012). A Re-Validation of the Students' Evaluation of Teaching Effectiveness Rating Scale. Ife Psychologia, 20(2), 220-233.

Nunally, JC., \& Bernstein, M I H. (1994). Psychometric Theory ( $3^{\text {rd }}$ ed.). New York: MCGraw Hill.

Opu, S. (2008). Motivation and Work Performance: Complexities in Achieving Good Performance Outcomes [dissertation]. [The Hague, Netherlands]: Institute of Social Studies, 2008.

Toland, MD., \& De Ayala, RJ. A. (2005). Multilevel Factor Analysis of Students Evaluation of Teaching. Educational and Psychological Measurement, 65(2), 272-296. http://dx.doi.org/10.1177/0013164404268667

Tschannen-Moran, M., Woolfolk-Hoy, A., \& Hoy WK. (1998). Teacher efficacy: Its meaning and measure. Review of Educational Research, 68, 202 -248. http://dx.doi.org/10.3102/00346543068002202

Westen, D., \& Rosenthal, R. (2003). Quantifying construct validity: Two simple measures. Journal of Personality and Social Psychology, 84(3), 608-618. http://dx.doi.org/10.1037/0022-3514.84.3.608

Wood, R. (2000). Work Motivation: Theory, Research and Practice. Journal of Applied Psychology, 49, 317-318. http://dx.doi.org/10.1111/1464-0597.00017 